\title{
Influence of the Number of Animals per Cage on the Anxiety Levels in Mice
}

\author{
Influência do Número de Animais por Gaiola sobre o Nivel de Ansiedade em Camundongos
}

\section{Pedro Martins Bellei ${ }^{1}$, Samuel Campos Gomides ${ }^{1}$, José Olimpio Tavares de Souza ${ }^{1}$, Carlos Alberto Mourão-Júnior ${ }^{2}$}

\begin{abstract}
This study aimed to evaluate the effect of the number of animals per cage behaviour of anxiety in mice exposed to elevated plus-maze. Thirty Swiss mice were divided into 2 groups: group 1 (G1) and group 2 (G2) with 10 and 20 animals respectively in each cage. Upon reaching 90 days of age, each animal was submitted to the elevated plus-maze, only once in the period of 5 minutes. The parameters evaluated in both groups were: percentage of the number of entries in open arm $(\% \mathrm{nBA})$ and percentage of time spent in open arms (\% tBA). The statistical analyis did not yield significant difference between the two groups in regarding \%nBA $(p=0.87)$ nor with respect to $\mathrm{tBA} \%(p=$ $0.98)$. Our work concluded that the maintenance of 10 or 20 mice per cage did not cause any significant alteration in the anxiety levels of the animals, thus it suggests being indifferent to maintain 10 or 20 mice per cage.
\end{abstract}

Keywords. Animal Behavior, Anxiety, Elevated Plus-Maze.

Citation. Bellei PM, Gomides SC, Souza JOT, Mourão-Júnior CA. Influence of the Number of Animals per Cage on the Anxiety Levels in Mice.

\section{RESUMO}

Este estudo teve como objetivo avaliar o efeito do número de animais por gaiola sobre o comportamento de ansiedade em camundongos expostos ao labirinto em cruz elevado. Trinta camundongos foram divididos em dois grupos: grupo 1 (G1) e 2 (G2) com 10 e 20 animais, respectivamente, em cada gaiola. Ao atingir 90 dias de idade, cada animal foi submetido ao labirinto em cruz elevado, apenas uma vez no período de 5 minutos. Os parâmetros avaliados em ambos os grupos foram: porcentagem do número de entradas nos braços abertos (\% NBA) e a porcentagem de tempo gasto nos braços abertos (\% TBA). A análise estatística não detectou diferenças significativas entre os dois grupos na \% NBA $(p=0,87)$, nem com relação à $\%$ TBA $(p$ $=0,98)$. O trabalho concluiu que a manutenção de 10 ou 20 animais por gaiola não causou nenhuma alteração significativa nos níveis de ansiedade dos mesmos, o que sugere ser indiferente manter 10 ou 20 camundongos por gaiola.

Unitermos. Comportamento Animal, Ansiedade, Labirinto em Cruz Elevado.

Citação. Bellei PM, Gomides SC, Souza JOT, Mourão-Júnior CA. Influência do Número de Animais por Gaiola sobre o Nível de Ansiedade em Camundongos.

Endereço para correspondência: Carlos Alberto Mourão-Júnior Universidade Federal de Juiz de Fora, Departamento de Fisiologia - ICB Campus Universitário S/N - Martelos Tel: +55-32-2102-3211 CEP 36036-900, Juiz de Fora-MG, Brasil. E-mail: carlos.mourao@uff.edu.br

Trabalho realizado no Laboratório de Neurofisiologia Cognitiva do Instituto de Ciências Biológicas da Universidade Federal de Juiz de Fora, Juiz de Fora-MG, Brasil.

1. Mestre em Ciências Biológicas, Universidade Federal de Juiz de Fora, Juiz de Fora-MG, Brasil.

2. Doutor em Medicina, Professor Adjunto de Departamento de Fisiologia da Universidade Federal de Juiz de Fora-MG, Brasil. 


\section{INTRODUCTION}

Nowadays, the maintenance of laboratory animals in the ideal conditions has been a focused study topic, once environmental factors as storage may interfere on the results of behavioral tests ${ }^{1}$. Based on the fact that rodents are social animals, keeping themselves among a group is indicated ${ }^{2}$. On the other hand, the interactions among individuals kept in a group, and the absence of these interactions by individuals kept isolated, should be evaluated in order to avoid wrong conclusions concerning the results of behavioral researches ${ }^{1}$.

The experimental analysis of the behavior is of extreme importance for biomedical researches on brain functions and on behavior ${ }^{3}$. One of the tools for the study of the behavior is the elevated plus-maze (EPM), which is considered the most precise instrument employed for the study of the anxiety behavior in mice ${ }^{4}$.

For many years, the EPM is recognized as a behavioral test broadly used worldwide. It is currently considered the best ethological measure of anxiety behavior, not only in mice but also in other mammals ${ }^{5,6}$. One reason for the wide acceptance of the EPM is the simplicity of the test run. According to current protocols, a single test lasting 5 minutes is enough to get reliable measures of anxiety levels in several animal models ${ }^{7,8}$.

Several factors have been suggested as being capable of producing anxious behavior in mice. Among these factors, some studies point to the importance of variables related to housing conditions ${ }^{9,10}$. Grouping housing in male mice was verified to be a stress factor ${ }^{11}$. However, when they are kept isolated, males show higher exploration in the labyrinth, reflecting a more aggressive and territorialist behavior ${ }^{12}$. Yet on females, group housing reduces anxiety 11 , and loneliness itself may even cause depression symptoms (high anxiety, low exploration) ${ }^{12}$.

In the laboratories, mice (Mus musculus) are kept in cages, but the number of individuals per cage may vary from one experiment to another, and not always these details are taken into account when data are analyzed. Perhaps this occurs because only recently the researchers began to be concerned about variables related to bioterism ${ }^{13,14}$.

Therefore, the objective of this study was to evaluate the effect of the number of animals per cage on the anxiety behavior in mice when exposed to the EPM.

\section{METHOD}

A total of 30 swiss male mice were obtained from the biotery of the Reproduction Biology Center of the Federal University of Juiz de Fora. The study was approved by the local ethics committee (Protocol \#004/2009 - CEEA/ UFJF). These animals were divided in 2 groups after weaning: group 1 (G1) and group 2 (G2) with 10 and 20 animals, respectively, in each cage ( $49 \times 34 \times 16 \mathrm{~cm}$ ), provided with food and water ad libitum. When they reached 90 days of age, each animal was submitted to the EPM, only once within a 5-minute period. The device had the following features: arms $8 \times 30 \mathrm{~cm}$; height of closed arms $20 \mathrm{~cm}$; center $8 \times 8 \mathrm{~cm}$; height above the floor $50 \mathrm{~cm}$; ledges of open arms $0.5 \mathrm{~cm}$.

The test started with the animal placed in the center of the apparatus, facing the open arm, over a 5-minute period. For the reason that the degree of anxiety of a mouse is directly related to the avoidance tendency of the animal toward the open arms of the EPM, with preference for the closed arms, we used two percentage parameters as indicators of anxiety. The first parameter evaluated was the percentage of entries in the open arms ( $\%$ nOA), obtained by [open entries / (open + enclosed entries)] x 100. The second parameter was the percentage time spent in the open arms (\% tOA), obtained by [open arm time / (open + enclosed arms time)] x 100. The utilization of $\% \mathrm{nOA}$ and $\% \mathrm{tOA}$, instead of using only the simple measurement of the number of entries and the time spent in the open arms, has the advantage of controlling an important intervenient variable which is the locomotor activity of the animal, because by measuring the activity degree in the open arms in relation to the activity in both arms, the effects of a higher or lower exploration activity are corrected ${ }^{4,15}$. The parameters of activity in the EPM were registered through the software Hindsight version 1.5 (Dr. Scott Weiss, 1995, University of Leeds, UK), used in behavioral analyses. It was used the software Prism version 5.00 (GraphPad Software, San Diego, California - USA) in the statistical analysis of data.

\section{RESULTS}

The parameters evaluated in both groups were: percentage of the number of entries in the open arms (\% $n O A)$ and the percentage time spent in the open arms 
(\% tOA). The results (average rating \pm standard mistake) of group $1(\mathrm{n}=10)$ were $47.5 \pm 3.9(\% \mathrm{nOA})$ and 55.1 $\pm 5.6(\%$ tOA $)$. In group $2(\mathrm{n}=20)$, the results were $43.4 \pm 1.4(\% \mathrm{nOA})$ and $53.4 \pm 2.2(\% \mathrm{tBA})$. Due to the difference in the number of animals and to the asymmetric distribution of group data, it was performed the non parametric test of Mann-Whitney in order to compare the parameters between groups 1 and 2 . The test did not verify any significant statistical difference neither in relation to the $\% \mathrm{nOA}(\mathrm{U}=83, p=0.87)$ nor in relation to the $\%$ tOA $(\mathrm{U}=99, p=0.98)$. The results are demonstrated in Table 1 and in Figure 1.

Table 1

Data referring to the descriptive statistics of the studied groups

\begin{tabular}{cccc}
\hline Group & $\mathbf{n}$ & \% nOA & \% tOA \\
\hline 1 & 10 & $47.5 \pm 3.9[42.8]$ & $55.1 \pm 5.6[51.2]$ \\
2 & 20 & $43.4 \pm 1.4[42.5]$ & $53.4 \pm 2.2[53.2]$ \\
\hline
\end{tabular}

Data expressed as: mean \pm standard error [median]. \%nOA: percentage of entries in open arms. \%tOA: percentage of time spent in open arms.

\section{DISCUSSION}

Some works ${ }^{16,17}$ showed that in larger cages there were more agressive occurences among male mice. This result may be explained by the fact that, by creating more room inside the cages, the terriorialist tendency and/or behavior increases. This agressive behavior could be considered a stressing and ansiogenic factor. However, in our study there was no difference concerning the anxiety levels between the two groups studied in the EPM test. It is possible to occur a stress tendency on the first days, but as time goes by, the animal tend to get used to the group, once mice apparently may be kept in large densities ${ }^{18}$.

Studies relating the behavior in the EPM to the number of animals per cage demonstrate dissonant results. Did not find any behavioral difference in mice kept in groups or isolated ${ }^{1}$. A study ${ }^{19}$ observed that mice kept isolated showed themselves less anxious than those in groups.

Other works ${ }^{19,20}$ demonstrated that swiss male mice when isolated were more anxious than those in groups. Maybe our results may not coincide with any of these experiments by the fact that all of them compared animals

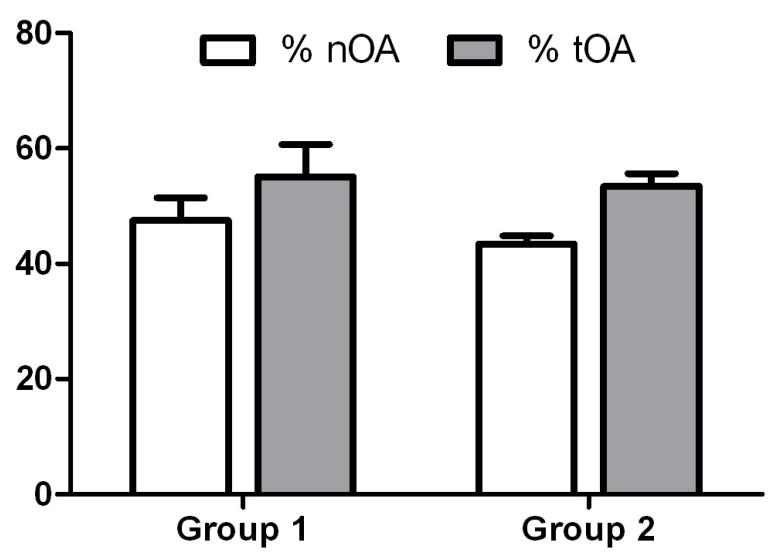

Figure 1. Comparison between the percentage of entries (white bar) and the time spent (gray bar) in the open arms among groups with 10 (Group 1) and 20 (Group 2) animals. The bars represent the mean, and the vertical lines represent the standard error. \%nOA: percentage of entries in open arms. \%tOA: percentage of time spent in open arms.

in a group with an isolated animal. Find the reasons for such variability is, however, often far from straightfor$\operatorname{ward}^{21}$. The fact is that several parameters may vary widely among different laboratories, and it seems that the factors that could account for different results in the literature regarding behavioral tests are not clear yet ${ }^{22}$. In order to try to elucidate the reasons of such variability, the ethological studies may continue to play a role in cognitive biology ${ }^{15}$. We did not find in the literature an experiment like this one by ourselves, comparing different numbers of animals per cage.

\section{CONCLUSION}

Our work concluded that the maintenance of 10 or 20 mice per cage did not cause any significant alteration in the anxiety levels of the animals, when they were exposed to the EPM, thus it suggests being indifferent to maintain 10 or 20 mice per cage. New research may corroborate our findings.

\section{REFERENCES}

1.Arndt SS, Laarakker MC, van Lith HA, van der Staay FJ, Gieling E, Salomons AR, et al. Individual housing of mice-impact on behaviour and stress responses. Physiol Behav 2009;97(3-4):385-93.

http://dx.doi.org/10.1016/j.physbeh.2009.03.008 
2.National Research Council. Guide for the care and use of laboratory animals. Washington D.C.: National Academy Press; 1996, p.21-48.

3.van der Staay FJ. Animal models of behavioral dysfunctions: basic concepts and classifications, and an evaluation strategy. Brain Res Rev 2006;52:131-59. http://dx.doi.org/10.1016/j.brainresrev.2006.01.006

4.Rodgers RJ, Dalvi A. Anxiety, defence and the elevated plus-maze. Neurosci Biobehav Rev 1997;21:801-10.

http://dx.doi.org/10.1016/S0149-7634(96)00058-9

5.Rodgers RJ, Johnson NJ. Factor analysis of spatiotemporal and ethological measures in the murine elevated plus-maze test of anxiety. Pharmacol Biochem Behav 1995;52:297-303.

http://dx.doi.org/10.1016/0091-3057(95)00138-M

6.Lister RG. The use of a plus-maze to measure anxiety in the mouse. Psychopharmacology (Berl) 1987;92:180-5.

http://dx.doi.org/10.1007/BF00177912

7.Walf AA, Frye CA. The use of the elevated plus maze as an assay of anxietyrelated behavior in rodents. Nat Protoc 2007;2:322-8.

http://dx.doi.org/10.1038/nprot.2007.44

8.Huang P, Liu-Chen LY, Kirby LG. Anxiety-like effects of SR141716-precipitated delta9-tetrahydrocannabinol withdrawal in mice in the elevated plusmaze. Neurosci Lett 2010;475:165-8.

http://dx.doi.org/10.1016/j.neulet.2010.03.071

9.Wall PM, Messier C. Methodological and conceptual issues in the use of the elevated plus-maze as a psychological measurement instrument of animal anxiety-like behavior. Neurosci Biobehav Rev 2001;25:275-86.

http://dx.doi.org/10.1016/S0149-7634(01)00013-6

10.Blizard DA, Weinheimer VK, Klein LC, Petrill SA, Cohen R, McClearn GE. 'Return to home cage' as a reward for maze learning in young and old genetically heterogeneous mice. Comp Med 2006;56:196-201.

11.Brown KJ, Grunberg NE. Effects of housing on male and female rats: crowding stresses male but calm females. Physiol Behav 1995;58:1085-9.

http://dx.doi.org/10.1016/0031-9384(95)02043-8

12.Palanza P, Gioiosa L, Parmigiani S. Social stress in mice: gender differences and effects of estrous cycle and social dominance. Physiol Behav 2001;73:411-20. http://dx.doi.org/10.1016/S0031-9384(01)00494-2

13.Gasparotto OC, Lopes DM, Carobrez SG. Pair housing affects anxiety-like behaviors induced by a social but not by a physiological stressor in male Swiss mice. Physiol Behav 2005;85:603-12.

http://dx.doi.org/10.1016/j.physbeh.2005.06.014

14.Bourin M, Petit-Demouliere B, Dhonnchadha BN, Hascoet M. Animal models of anxiety in mice. Fundam Clin Pharmacol 2007;21:567-74.

http://dx.doi.org/10.1111/j.1472-8206.2007.00526.x

15.Carobrez AP, Bertoglio LJ. Ethological and temporal analyses of anxietylike behavior: the elevated plus-maze model 20 years on. Neurosci Biobehav Rev 2005;29:1193-205.

http://dx.doi.org/10.1016/j.neubiorev.2005.04.017

16.Van Loo PL, Mol JA, Koolhaas JM, Van Zutphen BF, Baumans V. Modulation of aggression in male mice: influence of group size and cage size. Physiol Behav 2001;72:675-83.

http://dx.doi.org/10.1016/S0031-9384(01)00425-5

17.Fullwood S, Hicks TA, Brown JC, Norman RL, McGlone JJ. Floor Space Needs for Laboratory Mice: C56BL/6 Males in Solid-bottom Cages with Bedding. Ilar J 1998;39:29-36.

18. Olsson IAS, Westlund K. More than numbers matter: the effect of social factors on behaviour and welfare of laboratory rodents and non-human primates. Applied Animal Behaviour Science 2007;103:229-254.

http://dx.doi.org/10.1016/j.applanim.2006.05.022

19.Voikar V, Polus A, Vasar E, Rauvala H. Long-term individual housing in $\mathrm{C} 57 \mathrm{BL} / 6 \mathrm{~J}$ and DBA/2 mice: assessment of behavioral consequences. Genes Brain Behav 2005;4:240-52.

http://dx.doi.org/10.1111/j.1601-183X.2004.00106.x

20.Ferrari PF, Palanza P, Parmigiani S, Rodgers RJ. Interindividual variability in Swiss male mice: relationship between social factors, aggression, and anxiety. Physiol Behav 1998;63:821-7.

http://dx.doi.org/10.1016/S0031-9384(97)00544-1

21.Kalueff AV, Wheaton M, Murphy DL. What's wrong with my mouse model? Advances and strategies in animal modeling of anxiety and depression. Behav Brain Res 2007;179:1-18.

http://dx.doi.org/10.1016/j.bbr.2007.01.023

22.Levitis DA, Lidicker WZ, Freund G. Behavioural biologists don't agree on what constitutes behaviour. Anim Behav 2009;78:103-10.

http://dx.doi.org/10.1016/j.anbehav.2009.03.018 